\title{
MODERN UKRAINIAN DRAMA: RAPPORT BETWEEN AUTOR AND READER (BASED ON SOCIOLINGUISTIC SURVEY)
}

\author{
Valeriia Korolova \\ Department of Ukrainian Language \\ Oles Honchar Dnipropetrovsk National University \\ 72 Gagarin ave., Dnipro, Ukraine, 49010 \\ valeria.korolyova2015@gmail.com
}

\begin{abstract}
The article provides results of a sociolinguistic survey conducted among students in order to determine successful or unsuccessful encoding of information by author in paratext elements of modern Ukrainian plays. The research confirmed advanced hypothesis and proved that the majority of respondents expect shock and experiments from modern dramas. 250 respondents, who are students of Oles' Honchar Dnipro National University Faculty of Ukrainian and Foreign Philology and Arts, aged 19 to 23, have completed a questionnaire. These were students of philological department, whose professional qualification requires knowledge of works of art, including dramas, selected as respondents since modern Ukrainian drama tends to be rather unpopular and readers are disinterested in reading plays. Analysis of the responses to the questionnaire showed that paratext elements shape future hypothetical communication between author and reader, as well as provide the later with a certain set of expectations from reading the drama text. Genre features of drama stipulate a rich ground for reader's imagination, the range of which has diametrical limits and which determines recipient's personality. Association experiment proved consistency of reader's perception of author's intentions.
\end{abstract}

Keywords: sociolinguistic survey, Modern Ukrainian Drama, postmodernism, paratext elements, information "decoding".

\section{Introduction}

As any art, dramaturgic communication implies an active author and a passive reader who is imaginative, probable and generalized for the former and whose communicative activity is unknown to the author and is only hypothetically projected by an addresser. However, potential reader as communication participant is a key factor in the choice of explication language means of the author, which leads to high pragmatic potential of a play and successful aesthetic impact on the reader.

Reading dramatic work is closely linked to recognition process which "implies establishment of similarity between what is being perceived and what is already known" [1]. Recognition process appears to be most important at the stage of first-time reading of the play, including its title, genre-defining subtitle, dedication, list of characters. These paratext components of dramatic work demonstrate author's preview of further plot and events of the play, reader's interest in this work, which causes pragmatic significance of the components of dramatic text.

A sociolinguistic survey was conducted in order to identify whether author's encoding of information in paratext elements of the play was successful or not. The findings revealed potential readers' reactions to the proposed names of modern Ukrainian plays, typical predictions of the content of dramatic works and willingness to read them based on their title.

Sociological survey is not a new method in modern linguistics and is actively applied in scientific research on the problems of bilingualism and surzhyk (L. Masenko [2], A. Ruda [3], S. Sokolova [4]), on the features of sociolects (O. Danilevska [5], L. Lysak [6], A. Bolkova [6]), on the study of interpersonal conflict (L. Bilokonenko [7]).

\section{Aims of the research}

The initial hypothesis which lay the ground for our survey is as follows: young readers are eager to encounter scandalous behavior and eccentricity in modern dramas; “decoding” of author's information in paratext elements of plays arose from individual peculiarities of potential readers. 


\section{Methods of the research}

With help of a group survey 250 respondents aged 19 to 23, students of the Faculty of Ukrainian and Foreign Philology and Art in Dnipro National University Oles Honchar, were interviewed. Relevant information was collected at extra-curricular meetings with a group supervisor from students of III-V courses who were offered 20 different questions. The choice of informants can be justified by two reasons. Firstly, current lack of popularity of Ukrainian drama and absence of readers' interest in plays resulted in selecting students of philological department since their qualifications require knowledge of fiction, including drama. Secondly, their reading experience enables to define precision and suitability of author's paratext elements of modern drama correctly. This time results of our survey not only show readers' interpretation of author's encoding of certain information, but also determine horizons of readers' expectations from modern drama.

\section{Questionnaire sample}

1. Do you read modern plays?
A. Yes.
B. No.

2. Works of which modern playwrights do you know?
A. Ya. Vereshchak.
B. N. Nezhdana.
D. P. Arie.
E. S. Shchuchenko.
C. O. Mykolaychuk-Nyzovets.
G. A. Bahriana.
H. No one
F. V. Serdiuk.
I. Your option

3. Which directions, in your opinion, are more typical for modern Ukrainian drama (select 1-2 options)?
A. Romanticism.
B. Absurdism.
C. Postmodernism.
D. Realism.
E. Your option

4. Which paratext component, to your mind, is the least significant for dramas?
A. Genre-defining subtitle.
B. List of characters.
C. Dedication.
D. Epigraph.
E. Title.

5. Select three of the below mentioned plays which you would like to read.
A. "Icon".
B. "Glory to the heroes".
C. "The gods are dying of boredom".
D. "Crazy".
E. "Interrogation of the dead".
F. "Hope".
G. "Token".
H. "Pornography".
I. "Lizykava".
J. "Summer is almost gone".

6. Classify the below mentioned plays as to the century in which they were written (XIX, XX or XXI). There are five plays for each century.

"Rainbow” (1), "Marusia Shurai” (2), “Association Pshyk” (3), “Oksana” (4), "Khulii Khuryna" (5), "Smart and fool” (6), "Plasticine metal" (7), "Rush-catchers" (8), "Defense of Busha" (9), "Pork liver" (10), "Two families" (11), "Earthly sea" (12), "Mushrooms seem to be meat for the hungry" (13), "Shaggy-legged" (14), "Recording" (15).

\begin{tabular}{|c|c|c|}
\hline XIX century & XX century & XXI century \\
\hline & & \\
\hline
\end{tabular}

7. Which title embraces the main topic of the play best of all?

A. "Desire for extreme" - a play about a new kind of relax for the rich - "a weekend" in jail;

B. "Romeo and Jasmin" - names of two characters in love with each other;

C. "It is better to eat a brick" - a play about relationships between subordinates and an autocratic manager;

D. "Station" - a play about a mysterious station which you cannot leave.

8. Which title embraces the main topic of the play best of all?

A. "About train, suitcases, junk and something else" - a story about tragic love.

B. "Gastarbeiters' seasons" - a play about life of Ukrainian migrant workers in Germany.

C. "David" - a drama about life of David and his big family.

D. "Treat me with nuts" - a play about relationships between men and women with the slogan "Do not restrain your desires!" 
9. Try to determine plot of the play "Rhododendron" by its title.
A. This is the name of a wedding agency where the events take place.
B. "This is the name of a flower which symbolizes love between main characters".
C. "This is the name of a character, landed on the Earth from space".
D. "This is the name of a family estate in England".

10. Try to define plot of the play "Marinated aristocrat" by its title.

A. A play about the career of a poor cook who dreams of making a fortune and fame with help of a mysterious recipe of marinade.

B. The title explains the final part of the play in which the main character is killed and marinated in formalin.

C. A play about family life of an oligarch who dreams of purchasing the earl title.

11. Try to determine plot of the play "Last slaughter" by its title.

A. A play about an unsuccessful entrepreneur, who had to slaughter all the animals in the farm that went bankrupt.

B. A play about an accident in the mine.

C. A play about bloody clashes between members of criminal youth gangs that conflict.

12. Try to determine plot of the play "Buy the lunar path!" by its title.

A. A play about entrepreneurs, who are selling land on the Moon.

B. A story of unhappy love, the symbol of which was a Moon path (as a combination of night and moonlight).

C. A play about stealing an ancient fresco "Moon Path" two young female criminals.

13. Choose the title of a play for the following plot: a young film director Genio Bobyk wants to produce a play of Eugène Ionesco that is his desired wish. Looking for money, Genio has more and more debts and his wife leaves him. Finally, selling a part of his liver to donors, Genio does produce a play.
A. "Crazy director".
B. "iDream”.
C. "Everything for the performance".
D. "Money and Ionesco".
E. "Genio and Ionesco".
F. "Idée fixe".

14. Choose a title for a play with the following plot: a young architect Viktor, having come back after studies in Europe, is working on an order from a new city administration. However, his creativity is broken against the walls of bureaucracy and bribery. So he faces the choice: to come back abroad or to get adjusted to the reality of Motherland. He opts for the later.
A. "Do not show up!'
B. "Unclassical person".
C. "Other time".
D. "Architect".
E. "Building".
F. "Return".

15. Identify the title of a play about love and family relationships of a classic Russian author Leo Tolstoy and his wife Sofia; about timeless values of a human being: love, hatred, creativity.
A. "Lion and lioness".
B. "Family passion".
C. "Paper frigates".
D. "War and peace".
E. "Hedonism of creativity".
F. "The Tolstoy family".

16. Select the title of a play in which actions take place during a festive dinner of friends where host's sister invited a foreigner called Bob. At first, all characters try to interest Bob, to attract his attention. He is told about soviet regime, Western values are compared with those in their country. At the end, the characters are disappointed with a foreigner and decide that he is a spy.
A. "What do you like?"
B. "Dinner in circle of friends".
C. "Feast poetics".
D. "Insiders and outsiders".
E."Foreigner".
F. "At the table".

17. Determine which of the suggested plays are comedies (choose two options).
A. "Night of wolves".
B. "David".
C. "In salamanders siege".
D. "Petro Palace".
E. "Two under a blanket".
F. "Secret of existence".

18. Determine which of the suggested plays are tragedies (choose two options).
A. "Bizarre Messalina”.
B. "Area B".
C. "Night in the elevator".
D. "Traces of yesterday sand".
E. "Pryimaky".
F. "Female criminals". 
19. Determine the effect of dedication on the perception of a drama text (e. g.: to Honcharenko Oksana, In memory of Isadora Duncan).

A. Dedication does not influence further perception of a play.

B. Plays which have dedication to be of value for their authors and of interest to readers.

C. Dedication has an impact only as long as they know the person mentioned in it.

D. Dedication is generally not typical for playwrights, its usage will be considered as a disadvantage.

20. Which genre-defining subtitle of a play would make you interested in reading the play?

A. "Dearest friends" - a fatal tragicomedy in a pleasant company.

B. "Dog Liu" - an absurd comedy with a thunderstorm instead of swearing.

C. "Anniversary surprise" - a comedy.

D. "Life for three" - a melodramatic tragic glitch accompanied by a call.

E. "Felichita"- a play for an alarm clock.

F. "Secret of existence" - a drama.

Thank you for collaborating!

\section{Processing of the applied data}

The analysis of answers to the first question "Do you read modern plays?" proved an obvious trend of ignoring dramas by modern readers, including dramas in Ukrainian. 208 respondents answered "No" while only 42 replied "Yes", which proves lack of interest of modern young adults in reading dramas. This trend is highlighted by a number of theatre critics and literary scholars. In particular, O. Bondareva indicates: "While neighboring countries "water" and "feed" new drama on fertilizers, Ukrainian drama resembles a tree which managed to grow up on bare stones on a rock open to all winds and merciless sun" [8].

In this case one can logically predict answers to the question "What modern playwrights do you know?" with the following options: P. Arie, A. Bahriana, Ya. Vereshchak, O. Mykolaychuk-Nyzovets, N. Nezhdana, V. Serdiuk, S. Shchuchenko. The following playwrights appeared to be most known:

- Neda Nezhdana (16\%);

- V. Serdiuk (10\%);

- Ya. Vereshchak (8 \%);

- A. Bahriana (3,5\%);

- S. Shchuchenko (1\%);

- $54 \%$ of respondents replied "None";

$-7,5 \%$ of respondents offered their own option, namely:

a) Ukrainian playwrights (O. Irvanets, L. Podervianskyi);

b) Ukrainian prose writers and poets (S. Zhadan, O. Zabuzhko, Yu. Izdryk);

c) foreign playwrights (Hr. Boychev, Y. Grishkovetz).

The discrepancy between answers to the first and second questions can be explained by the fact that students of philological department might know particular names of playwrights even not reading their plays, for example, from the lectures which they attend at the faculty.

Focus on a particular literary movement is a significant factor in the formation of readers' expectations regarding this or that dramatic text. The third question was created in order to find out the directions which, to students' mind, are typical for modern Ukrainian drama. Postmodernism and absurdism appeared to be the most common directions while realism turned out to be less widespread. Respondents also selected:

- realism $-5,5 \%$;

- absurdism and realism $-4 \%$;

- romanticism $-3 \%$;

- romanticism and postmodernism - $1 \%$.

The fourth question was formed to define less significant paratext components of a drama. Answers to this question enabled to highlight the importance of certain components of author's 
direct party that affect further perception of a play by the reader. The survey results determined the following components as least significant:

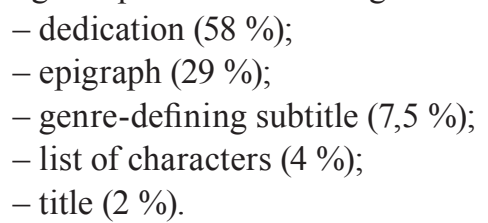

The fifth question asked respondents to select one title which they would like to read from the ten offered. The analysis of answers determined pragmatic focus of readers on further drama work perception depending on the title. The following plays interested the respondents:

- "Bohy vmyraiut vid nudhy" ("The gods are dying of boredom") - $22 \%$;

- "Kreizi” ("Crazy”) - 15 \%;

- "Slava heroiam" ("Glory to the heroes") - $15 \%$;

- "Dopyt nebizhchyka" ("Interrogation of the dead") - 12\%;

- "Lito maizhe mynulo" ("Summer is almost gone") - $10 \%$;

- "Nadiia" ("Hope") - $6 \%$;

- "Lizykava"- $6 \%$;

- "Zheton" ("Token") - $5 \%$;

- "Ikona" ("Icon") - $5 \%$;

- "Pornohrafiia" ("Pornography") - 4 \%.

Explanation of the benefits of unusual titles ("Gods die of boredom", "Crazy", "Interrogation of the dead") is justified by readers' expectations of modern literature, in particular drama, to be extraordinary, scandalous and possess new original forms. Choice of the name "Glory to the heroes" is motivated, in our opinion, by a recent surge of patriotic feelings.

The sixth question asked respondents to classify the plays according to the century when they were written (XIX, XX or XXI). 15 plays without names of authors (five plays for each century) were suggested: XIX century - "Rozumnyi i duren" ("Smart and fool”) (I. Karpenko-Karyi), "Oborona Bushi” ("Defense of Busha") (M. Starytskyi), "Dvi sim'i” (“Two families”) (M. Kropyvnytskyi), "Zhyteiske more” (“Earthly sea”) (I. Karpenko-Karyi), "Holodnomu i openky m'iaso" ("Mushrooms seem to be meat for the hungry") (I. Nechuy-Levytsky); XX century - "Marusia Shurai" (I. Mykytenko), "Tovarystvo Pshyk" ("Association Pshyk") (M. Irchan), "Khulii Khuryna" (M. Kulish), "Mohnonohe" ("Shaggy-legged") (V. Vinnichenko), "Veselka" ("Rainbow") (M. Zarudnyi); XXI century - "Plastylinovyi metal" ("Plasticine metal") (V. Kozhelianko, V. Serdiuk), "Oksana" (A. Denysenko), "Svyniacha pechinka" ("Pork liver") (S. Brama), "Kaifolovy" ("Rush-catchers") (V. Tarasenko), "Recording" (O. Irvanets).

Plays were chosen based on the criterion of the slightest ability to be identified by respondents. Taking into account their knowledge of theory of drama and history of Ukrainian drama that they received at school and in some cases already at university, students had to define the century when the play was created associating the name of the play and the literary features of a certain age. The answers proved the thesis that the reader expected scandal from modern drama. This is motivated by the fact that previous answers of respondents identified postmodernism and absurdism as leading literary trends of modern Ukrainian drama. The results showed correct century defining for the plays with titles which contained lexical items which are markers of a certain era. The use of such vocabulary and graphically not adapted English borrowings in titles made respondents select XXI century. This was proved by the percentage correlation of answers: $93,6 \%$ of respondents associated "Rush-catchers" with XXI century (234 responses), "Recording" - 88,8 \% (222 responses). Similarly to the famous works by Kropyvnytskyi "Dai sertsiu voliu, zavede v nevoliu" ("Give freedom to your heart and it will make you captive"), "Doky sontse ziide, rosa ochi vyist" ("Dew will devour eyes before the sunrise") and those by M. Starytski "Yak kovbasa ta charka, to mynetsia i svarka" ("With sausage and alcohol the quarrel will vapour"), in which aphorisms are verbalized, comedy "Mushrooms seem to be meat for the hungry" by I. Nechuy-Levytsky was identified correctly as well (203 answers). 
Ethnographism and folklorysm as dominant styles of Ukrainian drama of XIX century influenced the choice of respondents, who believed that a modern play "Oksana" with a traditional Ukrainian anthroponymicon in its title belonged to the heritage of XIX century (91\% of respondents). The fact that respondents associate modern drama with postmodern direction with its radicalism and inherent scandal explains selecting unusual titles as those belonging to modern plays. For instance, "Plasticine metal" and "Pork liver" were identified correctly (78\% and $52 \%$ of respondents respectively associated plays with XXI century), while "Shaggy-legged” by V. Vynnychenko was misidentified (85 \% of respondents). "Marusia Shurai" (1934) by I. Mykytenko was also associated incorrectly with XXI century. The latest can be explained by the fact that respondents, expecting denial by modern drama of ideals and values of the past, perceived the title as a transformation of a famous novel by Lina Kostenko.

The following plays were identified by their title correctly: "Defense of Busha", "Two families", "Smart and fool" - XIX century, "Rainbow", "Association Pshyk" - XX century. It should be noted that plays by M. Kulish "Khulii Huryna" and M. Irchan "Association Pshyk" were considered to belong to XXI by a number of respondents (29\% i $27 \%$ respectively). Plays entitled "Oksana", "Defense of Busha", "Smart and fool", "Mushrooms seem to be meat for the hungry", "Two families", "Earthly sea" were appointed to XXI century by fewer than $3 \%$ of respondents. Thus, determining century of a play by its title proved that potential youth is aimed at original, controversial and sarcastic modern works.

Questions 7-16 were formed to define successful or unsuccessful coding of certain information in titles of plays. In questions 7 and 8 respondents were offered to identify what titles cover the topics of plays best. The following replies for question 7 were offered:

A. "Zhaha ekstremu" ("Desire for extreme") - a play about a new kind of relax for the rich "a weekend" in jail;

B. "Romeo and Jasmin" - names of two characters in love with each other;

C. "Krashche z'isty kyrpychynu" ("It is better to eat a brick") - a play about relationships between subordinates and an autocratic manager;

D. "Stantsiia" ("Station") - a play about a mysterious station which you cannot leave. "Romeo and Jasmin" (34 \% of answers) and "Station" (29\% of answers) appeared to be most successful for respondents.

The following plays were suggested for question 8:

A. "Pro potiah, valizy, motlokh ta deshcho bilshe" ("About train, suitcases, junk and something else") - a story about tragic love;

B. "Hastarbaiterski sezony" (“Gastarbeiters' seasons”) - a play about life of Ukrainian migrant workers in Germany;

C. "Davyd" ("David") - a drama about life of David and his big family;

D. "Pryhosty mene horikhamy" ("Treat me with nuts") - a play about relationships between men and women with the slogan "Do not restrain your desires!". $44 \%$ of respondents selected "Gastarbeiters' seasons" to be the best title, 17 \% voted for "David".

Based on the results of the survey the following conclusion can be made: respondents believe that those titles which contain particular neutral information about main characters or events are successful and appropriate (“David", "Romeo and Jasmin", "Station”, “Gastarbeiters' seasons"). It should be pointed out that original metaphorical titles were chosen by the smallest number of respondents ("Treat me with nuts" - $11 \%$ of respondents, "It is better to eat a brick" - $12 \%$ of respondents).

Questions 9-12 suggested respondents to interpret the titles of plays "Rododendron" ("Rhododendron"), "Marynovanyi arystokrat" ("Marinated aristocrat"), "Ostannii zabii" ("Last slaughter"), "Kupit misiachnu dorizhku!" ("Buy the lunar path!”). That would enable us to determine author's plot information encoding in the title.

Question 9 requested to determine plot of the play "Rhododendron" by A. Bahriana, which actually is about relationships between colleagues in the wedding agency. The following options were proposed: 
A. This is the name of a wedding agency where the events take place;

B. "This is the name of a flower which symbolizes love between main characters";

C. "This is the name of a character who landed on the Earth from space";

D. "This is the name of a family estate in England". Only $8 \%$ of respondents selected the right answer (A), while $54,5 \%$ of respondents chose B.

Other two titles were also misinterpreted ("Last slaughter" by O. Rosych - about everyday life of miners; "Buy the lunar path!" by V. Tarasenko - about two sisters who were selling land on the Moon). Respondents suggested that the former was a play about bloody clashes between members of criminal youth gangs that conflict (48\%), while the correct option "a play about an accident in the mine" accounted for only 38,4\%. The later title was explained as "a play about stealing an ancient fresco "Moon Path" two young female criminals" (45\%). Two other options accounted for the same $25 \%$ : "a play about entrepreneurs who are selling land on the Moon" and "a story of unhappy love, the symbol of which was a Moon path (as a combination of night and moonlight)". To sum up, young female respondents defined the plot through values which count for them, namely family, welfare [9], which explains the priority of those options which contained plots about love. According to modern psychologists, aggressiveness and anxiety are the most common manifestations of personality for the young [10]. That is why respondents selected plots with criminal offences. In addition, both interpretations of plays contained a lexical unit "young" (members of criminal youth gangs, young female criminals).

The only play which title was interpreted correctly was a comedy of absurd by I. Koval "Marinated aristocrat". 51,5\% of respondents defined that the title explains the final part of the play in which the main character is killed and marinated in formalin. Other options (a play about the career of a poor cook who dreams of making a fortune and fame with help of a mysterious recipe of marinade) were chosen by far more seldom; about the career of a poor cook who dreams of making a fortune and fame with help of a mysterious recipe of marinade) were chosen by far more seldom (28,5\% and $20 \%$ respectively).

Questions 13-16 had a reverse direction and respondents needed to select the name of a play based on topics or plots described. It should be mentioned that out of four titles suggested respondents selected two correctly.

Question 13 offered to choose the title of a play for the following plot: a young film director Genio Bobyk wants to produce a play of Eugène Ionesco that is his desired wish. Looking for money, Genio has more and more debts and his wife leaves him. Finally, selling the biggest part of his liver to donors, Genio does produce a play. Options suggested were as follows:

- "Ideia fiks" ("Idée fixe") - $35 \%$;

- "Shalenyi rezhyser" ("Crazy director") - $24 \%$;

- "iDream" - $15 \%$;

- "Hroshi na Yonesko" ("Money and Ionesco") (the right option) - 10,5 \%;

- "Use dlia vystavy" ("Everything for the performance") - $14 \%$;

- "Genio i Yonesko" ("Genio and Ionesco") - 1,5\%.

Question 14 asked respondents to choose a title for a play with the following plot: a young architect Viktor, having come back after studies in Europe, is working on an order from a new city administration. However, his creativity is broken against the walls of bureaucracy and bribery. So he faces the choice: to come back abroad or to get adjusted to the reality of Motherland. He opts for the later. Options suggested were as follows:

- "Arkhitektor" ("Architect") - $26 \%$;

- "Ne vysovuisia!" (“Do not show up!") - 20,5\%;

- "Neklasychna liudyna" ("Unclassical person") (the right option) - $19 \%$;

- "Povernennia" ("Return") - $17 \%$;

- "Inshi chasy" ("Other time") - 12,5\%;

- "Budivlia" ("Building") - $5 \%$.

Question 15 requested respondents to identify the title of a play about love and family relationships of a classic Russian author Leo Tolstoy and his wife Sofia; about timeless values of a human being: love, hatred, creativity. The following results were got: 
- "Lev i Levytsia" ("Lion and lioness") (the right option) - $33 \%$;

- "Rodyna Tolstykh" ("The Tolstoy family") - 19\%;

- "Viina i myr" ("War and peace") - $15 \%$;

_ "Paperovi frehaty" ("Paper frigates") - $13 \%$;

_ "Simeini prystrasti" ("Family passion") - $12 \%$;

- "Hedonistyka tvorchosti" ("Hedonism of creativity") - $8 \%$.

Question 16 asked to choose the title of a play in which actions take place during a festive dinner of friends where host's sister invited a foreigner Bob. At first, all characters try to interest $B o b$, to attract his attention. He is told about soviet regime, Western values are compared with those in their country. At the end, the characters are disappointed with a foreigner and decide that he is a spy. Title "Svoi i chuzhi" ("Insiders and outsiders") accounts for the majority of choices $(30,5 \%)$. Other choices were made by a smaller number of respondents:

- "Inozemets" ("Foreigner") - $22 \%$;

- "Vecheria v koli druziv" ("Dinner in circle of friends") - $16 \%$;

- "Dovkola stolu" ("At the table") - 9,5\%;

- "Shcho Vam do vpodoby?" ("What do you like?") - $6 \%$;

- "Poetyka zastillia" ("Feast poetics") (the right option) - $16 \%$.

The chosen similar questions did not intend to determine the percentage of correct correlation between the title and plot of a play. The further was proved by results of the survey: respondents, expecting modern literature to possess unusual emotions, scandals, originality, as a rule opted for particular, neutral and not original titles of plays. These were titles which indicated characters' names or personal features ("Lion and lioness", "Architect", "Insiders and outsiders", "Foreigner", "Crazy director") or evaluated the actions ("Idée fixe", "Return", "Dinner in circle of friends"). Unusual titles ("What do you like?", "Hedonism of creativity, "iDream") were chosen by a great deal lower number of respondents.

Literary knowledge of potential philologists enabled correct genre defining of plays (questions 17-18). Question 17 asked to determine which ones of the suggested plays were comedies, choosing two answers. Possibility to choose two answers explains the fact that general number of answers can be more than $100 \%$. Respondents selected correct answers:

- "Petropalatsyk" ("Petro Palace") - $67 \%$;

- "Dvoie pid kovdroiu" ("Two under a blanket") - $79 \%$.

Other plays accounted only for a small percentage of choices:

- "Nich vovkiv" ("Night of wolves") - $6 \%$;

- "V oblozi salamandr" ("In salamanders siege") - $22 \%$;

- "Davyd" ("David") - 3,5 \%;

- "Taina buttia" ("Secret of existence") - $3 \%$.

The answers to question 18, in which respondents selected tragedies by titles of plays, were chosen correctly as well:

- "Slidy vchorashnoho pisku" ("Traces of yesterday sand") - $79 \%$;

- "Khymerna Messalina" ("Bizarre Messalina") - 39,5 \%.

However, other titles also account for a number of choices:

- "Terytoriia B" ("Area B") - $28 \%$;

- "Nich u lifti" ("Night in the elevator") - $22 \%$;

- "Pryimaky" - $20 \%$;

- "Shakhraiky" ("Female criminals") - $10 \%$.

Question 19 was aimed at determining the perception of a drama text which had a dedication (e. g.: to Honcharenko Oksana, In memory of Isadora Duncan). Despite the fact that $58 \%$ of respondents defined dedication the least significant component of a drama in question 4 , most of respondents $(84,5 \%)$ pointed out that dedication influences further reading. In this case $51,5 \%$ of them consider plays which have dedication to be of value for their authors and of interest to readers, while 48,5\% declare that dedication has an impact only as long as they know the person mentioned in it. $15,5 \%$ of respondents noted that dedication does not influence further perception of a play for 
them. The option "dedication is generally not typical for playwrights, its usage will be considered as a disadvantage" was not selected at all.

Question 20 aimed at determining significance of genre-defining subtitle in making readers interested in the play. The analysis of results proves that genres which break traditional rules of genre definition appear to be the most intriguing and encouraging reading further. The answers prove it:

$-25 \%$ of respondents would be interested in melodramatic tragic glitch accompanied by a call "Zhyttia na triokh" ("Life for three");

- $22 \%$ - in a fatal tragicomedy in a pleasant company "Liub'iazniishyi pryiatel" ("Dearest friends");

- $19 \%$ - in a play for an alarm clock "Felichita";

- $17 \%$ - in an absurd comedy with a thunderstorm instead of swearing "Sobaka Liu"

("Dog Liu"), the following titles were chosen as least genre defining:

- "Iuvileinyi siurpryz" ("Anniversary surprise") - a comedy (9\%);

_ "Taina buttia" ("Secret of existence") - a drama (8\%).

\section{Conclusions}

In a nutshell, the analysis of answers in the survey proved that paratext elements of modern plays form further hypothetical communication between reader and author, provide the former with certain expectations from reading the drama. The research confirmed our hypothesis and proved:

1) the majority of respondents expect shock and experiments from modern dramas;

2) philological experience of respondents enabled logical perception of paratext elements of drama and correct interpreting of author's intentions.

\section{References}

[1] Bilous, P. V. (2013). Teoriia literatury. Kyiv: Akademvydav, 328.

[2] Bilokonenko, L. A. (2015). Ukrains'komovnyj mizhosobystisnyj konflikt. Kyiv: Interservis, 335.

[3] Masenko, L. (2011). Surzhyk: mizh movoiu i iazykom. Kyiv: Kyjevo-Mogyljans’ka akademija, 137.

[4] Ruda, O. (2014). Dvomovnist' zasobiv masovoi komunikatsii v otsinkakh majbutnikh zhurnalistiv. Ukrains'ka mova, 3, 84-92.

[5] Sokolova, S. (2013). Osnovni typy movnoi povedinky kyian. Ukrains'ka mova, 2, 38-55.

[6] Danylevs'ka, O. (2013). Typy movnoi povedinky kyivs'kykh shkoliariv. Ukrains'ka mova, 2, 56-67.

[7] Lysak, L., Bolkova, O. (2012). Sotsial'nyj dialekt studentstva tekhnichnoho vyshu: kontseptosfery, sotsial'no-psykholohichni funktsii ta dzherela popovnennia. Linhvistychni studii, 25, 188-194.

[8] Bondareva, O. (2012). Proloh pered zavisoiu. Avanstsena: inform. zbirnyk suchasnoi ukr. dramaturhii. Kyiv, 5-6.

[9] Tseliakova, O. M. (2009). Dukhovnist' i tsinnisni oriientatsii students'koi molodi Ukrainy v transformatsijnomu suspil'stvi. Humanitarnyj visnyk ZDIA, 38, 222-233.

[10] Drozdov, O. Yu. (2003). Sotsial'no-psykholohichni faktory dynamiky ahresyvnoi povedinky molodi. Kyiv, 20. 